\title{
Consideration of quality change of railway transport maintenance operations in managing costs of goods transport
}

\author{
Lidia Shkurina ${ }^{1,1}$, Eugenia Maskaeva ${ }^{1}$, and Stanislav Maskaev ${ }^{1}$ \\ ${ }^{1}$ Russian University of Transport (RUT (MIIT)), Russia, Moscow
}

\begin{abstract}
. the authors reviewed the quality of operational work of railway transport in the cost management system, presented methods for assessing the impact of the quality of rolling stock on the current costs of transportation activities, considered the issues of the impact of the quality of operational work on the formation of freight market demand and of financial result of the transport company - the owner of infrastructure and traction rolling stock, represented methods of assessing financial and economic efficiency of improving the quality of operational work for the company - a participant of the freight market.
\end{abstract}

\section{Introduction}

Efficiency of cost management in a vertically integrated company, that operating in the freight market, is determined by three groups of factors: quality and price of the resources used, quality of operational work and professionalism of the cost management process participants. These three groups of factors are inextricably linked and each of them can play a key role in ensuring the systemic efficiency of freight cost management at a certain stage of the transportation life cycle. However, in our opinion, the factor of quality of operational work is primary for the company - the owner of infrastructure and traction rolling stock. It should be noted that today on this issue there is no standard regulation of indicators, that characterizing, for example, the quality of rolling stock use. This situation is caused by a number of reasons, among which we can note the organizational, technical and technological conditions, regional, topography and climatic factors affecting the level of wages, operating conditions and energy consumption. This list is not exhaustive, but reflects the main reasons why it is impossible to achieve common regulatory indicators on all railways. Table 1 presents an example of indicators characterizing the efficiency of locomotive fleet on the Russian Railways.

\footnotetext{
${ }^{1}$ Corresponding author: efut2012@gmail.com
} 
Table 1. Dynamics of locomotives use indicators for 2004-2016.

\begin{tabular}{|c|c|c|c|c|c|c|c|c|c|}
\hline Indicators & Units & 2004 & 2010 & 2011 & 2012 & 2013 & 2014 & 2015 & 2016 \\
\hline 1 & 2 & 4 & 10 & 11 & 12 & 13 & 14 & 15 & 16 \\
\hline $\begin{array}{l}\text { Average } \\
\text { daily mileage } \\
\text { of the } \\
\text { locomotive }\end{array}$ & $\mathrm{km}$ & 551,0 & $537,6^{1)}$ & $593,6^{2)}$ & 585,4 & 591,3 & $632,6^{3)}$ & 652,5 & n.d.a. \\
\hline $\begin{array}{l}\text { Growth rate } \\
\text { to previous } \\
\text { year }\end{array}$ & $\%$ & 102,6 & 91,2 & 110,4 & 98,6 & 101,0 & 107,0 & 103,1 & - \\
\hline $\begin{array}{l}\text { Local speed } \\
\text { of freight } \\
\text { train }\end{array}$ & $\mathrm{km} / \mathrm{h}$ & 39,6 & 41,2 & 37,1 & 36,0 & 36,8 & 37,7 & 39,1 & 39,7 \\
\hline $\begin{array}{l}\text { Growth rate } \\
\text { to previous } \\
\text { year }\end{array}$ & $\%$ & 101,5 & 99,0 & 90,0 & 97,0 & 102,2 & 102,4 & 103,7 & 101,5 \\
\hline $\begin{array}{l}\text { Technical } \\
\text { speed of the } \\
\text { freight train }\end{array}$ & $\mathrm{km} / \mathrm{h}$ & 47,5 & 49,3 & 46,5 & 45,2 & 45,6 & 45,6 & 46,4 & n.d.a. \\
\hline $\begin{array}{l}\text { Growth rate } \\
\text { to previous } \\
\text { year }\end{array}$ & $\%$ & 101,5 & 100,0 & 94,3 & 97,2 & 100,9 & 100,0 & 101,8 & - \\
\hline $\begin{array}{l}\text { Average } \\
\text { weight of } \\
\text { freight train }\end{array}$ & tons & 3670 & 3867 & 3868 & 3891 & 3911 & 3929 & 3966 & 4006 \\
\hline $\begin{array}{l}\text { Growth rate } \\
\text { to previous } \\
\text { year }\end{array}$ & $\%$ & 101,7 & 100,3 & 100,0 & 100,6 & 100,5 & 100,5 & 100,9 & 101,0 \\
\hline $\begin{array}{l}\text { The average } \\
\text { daily } \\
\text { capacity of } \\
\text { the } \\
\text { locomotive } \\
\text { of the } \\
\text { operating / } \\
\text { working fleet } \\
\text { in the freight } \\
\text { traffic }\end{array}$ & $\begin{array}{l}1000 \\
\text { tkm } \\
\text { gross }\end{array}$ & 1615 & $1725^{1)}$ & $1812^{2)}$ & 1791 & 1820 & $1965^{3)}$ & 2038 & 2097 \\
\hline $\begin{array}{l}\text { Growth rate } \\
\text { to previous } \\
\text { year }\end{array}$ & $\%$ & 103,2 & 96,6 & 105,0 & 98,8 & 101,6 & 108,0 & 103,7 & 102,9 \\
\hline
\end{tabular}

Where: ${ }^{1)}$ from July 1, 2010 by the order of JSC "Russian Railways" of 11.11.2009 № $2293 p$ approved and put into operation new indicators of the state and use of traction rolling stock;

2) from January 1, 2011 indicators are calculated for the locomotive fleet (Order of 02.09.2010 № $1854 \mathrm{p}$ "On the introduction of the average daily productivity of the locomotive of the working fleet in freight traffic"; 
3) the average daily productivity of the locomotive in 2014 and 2015 is not comparable with 2013 due to the change in the methodology of accounting for the locomotive fleet, Russian Railways order of 29.10.2012 № 2155p (acceptance / delivery of the locomotive by the locomotive crew in the depot of registration, movement of the locomotive crew from the end of acceptance to the passage of the checkpoint (CP) at the exit from the depot or from the passage of the $\mathrm{CP}$ before the start of the delivery of the locomotive at the entrance to the depot began to be taken into account in the non-working park);

4) The data are relevant for August 25, 2017.

\section{Materials and Methods}

It should be noted that in regional traction directorates and, consequently, in each locomotive operating depot, the average network indicators given in table 1 differ both in one direction and in the other. Improving the quality of operational work, including indicators of locomotive use, is a necessary condition for optimizing transportation costs.

The effectiveness of measures aimed at improving the quality of operational work can be determined on the basis of the criterion - profit from transportation activities [1]:

$$
E=\sum_{i=1}^{n} E_{i}\left(T_{i} ; \sum P l_{i}\right) \rightarrow \max
$$

where $E\left(T_{i} ; \sum P l_{i}\right)$ - the profit received from performance of transportations of i-kind in volume $\sum P l_{i}$ under the tariff $T_{i}$.

In this case, a value is determined at that profit value $\sum P l_{i}$, that assumes a maximum value under a number of restrictions. However, it is necessary to take into account the restrictions on the use of production resources and restrictions related to the possibility of expanding the market. Restrictions on the use of production resources are determined by:

$$
\sum_{i=1}^{n}\left[n_{i j} \cdot \sum P l_{i}\right] \leq R_{j},
$$

where $n_{i j}$ - is the rate of consumption of production resources of the $\mathrm{j}$-th type when performing the i-th type of transportation;

$R_{j}$ - the amount of resources of the $\mathrm{j}$-th type in the enterprise.

Subject to the restriction of traffic volumes and the expansion of the sales market, proceed from the following ratio:

$$
\sum P l_{i k}+\Delta \sum P l_{i k} \leq \sum P l_{i k}
$$

where $\sum P l_{i k}, \sum P l_{i k}$ - the volumes of transport of the i-th species on the k-th market of transport services are available and planned to be achieved;

$\Delta \sum P l_{i k}$ - planned increase in sales volumes of the i-th type of transportation on the k-th market of transport services (for each type of cargo).

Thus, based on the established limitations, the volume of traffic is determined, at which the profit will be maximum: 


$$
E=\sum_{i=1}^{n}\left[\sum_{k=1}^{k} \sum P l_{i k} \cdot T_{i}+\Delta \sum_{k=1}^{k} P l \cdot t_{i}-\Delta \sum P l_{i k} \cdot C\right],
$$

where $C$ - is the cost of transportation.

As a criterion of optimality, the costs of transportation realization can also be selected, which is typical for the strategy of "cost advantages". In this case, the amount of traffic that is selected is minimized:

$$
S=\sum_{i=1}^{n} C_{i}\left(\sum P l_{i}\right) \rightarrow \min
$$

As a limitation, only a shortage of productive resources is considered. Expansion of market share in this case is not considered and profit is determined:

$$
E=\sum_{i=1}^{n}\left[\sum P l_{i} \cdot T_{i}\right]-\sum_{i=1}^{n}\left[\sum P l_{i} \cdot C_{i}\right] .
$$

At the same time, such a volume of transportations of the i-th cargo is determined, under which the objective function is maximized with the appropriate resource constraint.

\section{Results}

The study [2] determined that the combination of the weight of the train and the speed of movement determines the carrying capacity of the railways, and hence the volume of supply of freight transportation services, which affects the completeness of the satisfaction of demand, and noted that the weight and speed of the trains take the leading place in the system of indicators characterizing the activities of the railway transport, significantly affecting the demand of the cargo owners and the cost of rail transportation. Provide the required increase in weight of the train and speed is possible only on the basis of innovative development of engineering and technology. Weight and speed of the train determines the productivity of locomotives - the most complex and capital-intensive technical means of railway transport. Accordingly, they have a significant impact on the productivity of locomotive teams - and this is the most skilled and highly paid working profession in the industry. Thus, the weight of the train and the speed of movement significantly affects the price parameters of the rail freight offer. In the current operational situation, it is often necessary to choose, in a varying degree, between weight growth and train speed. However, in the long run the growth of both weight and speed of trains is ensured.

One of the fundamental principles laid down in the functional strategy of quality management of JSC "Russian Railways" is the distribution of responsibility of branches and departments for the quality of the transportation process, failures of technical means, failures in providing the traffic schedule, train delays and other failures in the work. For a real assessment of the performance of branches in improving the quality of operational work based on the distribution of targeted responsibility, an economic effect or contribution to the financial result of the company should be assessed. In addition, it is necessary to address the problem of target motivation of the branches and relevant structural units for achieving and not achieving specified transport quality indicators [3].

To conduct a deeper analysis of the possibility of obtaining an effect from improving the quality of operational work, it is advisable to distribute the indicators in the following blocks:

- indicators characterizing the quality of rolling stock use;

- indicators characterizing the quality of repair of rolling stock; 
- economic losses that the company incurs from technical equipment failures;

- economic losses associated with traffic safety violations.

In the group of indicators characterizing the quality of rolling stock use, in addition to traditional indicators, it is proposed to include train-hours of train delays due to faults of structural units.

\section{Discussion}

The address determination algorithm of the impact of quality upon operational work, technical means failures and transport incidents on the financial result of the company, as well as calculation of the economic effect (losses) from changes in the quality indicators of the transportation process is presented in Table 2.

Table 2. Calculation of economic losses (effect) from changes in the quality indicators of the transportation process for the first half of 2018 (conditional data).

\begin{tabular}{|c|c|c|c|}
\hline \multirow{2}{*}{$\begin{array}{l}\text { Name of the } \\
\text { indicator }\end{array}$} & $\begin{array}{l}\text { Modific } \\
\text { ation of } \\
\text { the } \\
\text { meter }\end{array}$ & \multirow{2}{*}{$\begin{array}{l}\text { Algorithm for calculating the cost estimate of the } \\
\text { indicator }\end{array}$} & $\begin{array}{l}\text { Economic } \\
\text { losses "-" } \\
\text { (saving } \\
\text { "+"), mln. } \\
\text { rub. }\end{array}$ \\
\hline & $\begin{array}{c}\text { at } \\
\text { deviatio } \\
\mathrm{n} \text { from } \\
\text { the fact } \\
2017\end{array}$ & & $\begin{array}{c}\text { at } \\
\text { deviation } \\
\text { from the } \\
\text { fact } 2017\end{array}$ \\
\hline 1 & 3 & 4 & 6 \\
\hline \multicolumn{4}{|c|}{ Traffic Management Department } \\
\hline $\begin{array}{l}\text { Average idle of } \\
\text { transit wagon } \\
\text { with processing } \\
\text { at a technical } \\
\text { station, h }\end{array}$ & $-0,41$ & $\begin{array}{l}\qquad n t_{c / n}{ }^{*} e_{n t} \\
\Delta n t_{c / n} \text { - change of wagon-hours of idle transit } \\
\text { wagons at a technical station with processing, } \\
\text { wagon-hours } \\
e_{n t} \text { - consumption rate for 1 wagon-hour, rub. }\end{array}$ & 225,19 \\
\hline $\begin{array}{l}\text { Average idle of } \\
\text { transit wagon } \\
\text { without } \\
\text { processing at } \\
\text { the technical } \\
\text { station, h }\end{array}$ & 0,15 & $\begin{array}{l}\qquad \Delta n t_{b / n}{ }^{*} e_{n t} \\
\Delta_{n t_{b / n}} \text { - change of wagon-hours of idle transit } \\
\text { wagons at a technical station without processing, } \\
\text { wagon -hours }\end{array}$ & $-206,86$ \\
\hline $\begin{array}{l}\text { Train-hours of } \\
\text { freight train } \\
\text { delays caused } \\
\text { by the } \\
\text { Directorate of } \\
\text { Traffic Control }\end{array}$ & 9,5 & $\begin{array}{l}\qquad \Delta N t_{o p}^{c} * e_{N t}^{c} \\
\Delta N t_{o p}^{c} \text { - train-hours of freight train delays } \\
e_{N t}^{c}-\text { the cost rate for } 1 \text { train-hour of a freight } \\
\text { train, rub. }\end{array}$ & $-0,02$ \\
\hline $\begin{array}{l}\text { Trains-hours of } \\
\text { passenger train } \\
\text { delays caused } \\
\text { by the } \\
\text { Directorate of } \\
\text { Traffic Control }\end{array}$ & 2,2 & $\begin{array}{l}\qquad \Delta N t_{o p}^{p} * e_{N t}^{p} \\
\Delta N t_{o p}^{p}-\text { train-hours of passenger train delays } \\
e_{N t}^{p}-\text { the cost rate for 1 train-hour of the passenger } \\
\text { train in the long-distance, rub. }\end{array}$ & $-0,01$ \\
\hline
\end{tabular}




\begin{tabular}{|c|c|c|c|}
\hline $\begin{array}{l}\text { Train-hours of } \\
\text { suburban } \\
\text { electric trains } \\
\text { delays due to } \\
\text { the fault of the } \\
\text { traffic control } \\
\text { department }\end{array}$ & 1,3 & 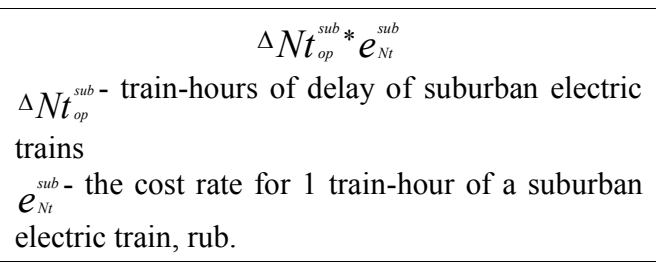 & $-0,01$ \\
\hline \multicolumn{3}{|c|}{ Total for the Traffic Management Department } & 18,29 \\
\hline \multicolumn{4}{|c|}{ Traction directorate } \\
\hline $\begin{array}{l}\text { Average daily } \\
\text { run of the } \\
\text { locomotive, } \\
\mathrm{km} / \text { day }\end{array}$ & -4 & $\begin{array}{l}\frac{\sum P l_{O}\left(1+\frac{q_{m}}{P_{d}^{l}}\right)}{Q_{b r}}\left(1+\beta_{a u x}\right)\left(\frac{1}{S_{2}}-\frac{1}{S_{1}}\right) * e M t \\
\sum P L_{o}^{-} \text {operating cargo turnover, million t-km } \\
q_{m} \text { - the average weight of the tare of the car, } \\
\text { tons } \\
P_{d}^{l} \text { - dynamic load of the working car wagon, } \mathrm{t} / \\
\text { wagon } \\
Q_{b r} \text { - gross weight of the train, tons } \\
\beta_{\text {aux }} \text { - coefficient of auxiliary linear run } \\
S_{1}, S_{2} \text { - the mean daily run of the locomotive } \\
\text { before the change, after the change, respectively, } \\
\text { km / day } \\
e_{M t} \text { - the charge rate for } 1 \text { locomotive-hour, rub. }\end{array}$ & $-2,12$ \\
\hline $\begin{array}{l}\text { Non-productive } \\
\text { losses of } \\
\text { working time of } \\
\text { locomotive } \\
\text { crews, h }\end{array}$ & 12947 & $\begin{array}{l}\qquad T_{u n} * e_{b r} \\
\Delta T_{u n} \text { - unproductive work of locomotive crews, } \\
\mathrm{h} \\
e_{b r} \text { - the charge rate for } 1 \text { brigade-hour of the } \\
\text { locomotive brigade, rub. }\end{array}$ & $-6,43$ \\
\hline $\begin{array}{l}\text { Average gross } \\
\text { weight of the } \\
\text { train, gross tons } \\
\text { / train }\end{array}$ & 58 & $\begin{array}{c}\sum^{P l_{o}}\left(\frac{q_{m}}{P_{d}^{l}}+1\right) *\left(\frac{1}{Q_{b r} 2}-\frac{1}{Q_{b r} 1}\right) \\
* e_{N S} \\
\boldsymbol{e}_{N S}-\text { the rate of expenditure for } 1 \text { train-km, rub. }\end{array}$ & 1102,9 \\
\hline $\begin{array}{l}\text { Excess of the } \\
\text { standard fuel } \\
\text { consumption } \\
\text { rate for traction, } \\
\mathrm{kg} / 10 \text { thousand } \\
\mathrm{t}-\mathrm{km} \text { gross }\end{array}$ & $-0,2$ & $\begin{array}{l}\qquad \frac{(1-\lambda) \sum P l_{b r}{ }^{*} \Delta a}{10000} * e_{m} \\
\Delta a-\text { change in the rate of specific fuel } \\
\text { consumption, } \mathrm{kg} / 10 \text { thousand t-km gross } \\
\lambda \text { - the share of electric draft in freight turnover } \\
e_{m} \text { - price of } 1 \mathrm{~kg} \text { of conventional fuel, rub. }\end{array}$ & 83,26 \\
\hline
\end{tabular}




\begin{tabular}{|c|c|c|c|}
\hline $\begin{array}{l}\text { Exceeding the } \\
\text { rate of } \\
\text { electricity } \\
\text { consumption for } \\
\text { traction, kWh / } \\
10 \text { thousand t- } \\
\text { km gross }\end{array}$ & -1 & 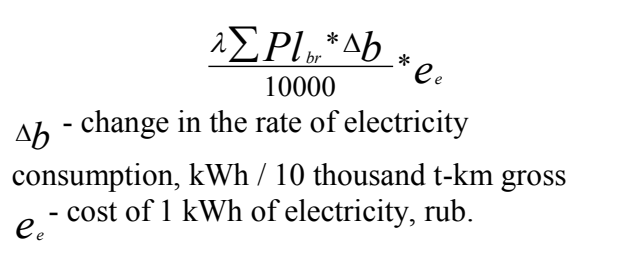 & 226,02 \\
\hline $\begin{array}{l}\text { Train-hours of } \\
\text { freight train } \\
\text { delays due to } \\
\text { fault of the } \\
\text { Traction } \\
\text { directorate }\end{array}$ & 14196 & $\begin{array}{l}\qquad \Delta N t_{o p}^{c}{ }^{*} e_{N t}^{c} \\
\Delta N t_{o p}^{c}-\text { train-hours of freight train delays due to } \\
\text { locomotive depots and maintenance faults }\end{array}$ & $-25,3$ \\
\hline $\begin{array}{l}\text { Train-hours of } \\
\text { delays of } \\
\text { passenger trains } \\
\text { through the } \\
\text { fault of the } \\
\text { Traction } \\
\text { directorate }\end{array}$ & 1086,8 & $\begin{array}{c}\Delta N t_{o p}^{p} * e_{N t}^{p} \\
\Delta N t_{o p}^{p}-\text { train-hours of passenger train delays } \\
\text { caused by locomotive depots and maintenance }\end{array}$ & $-4,22$ \\
\hline $\begin{array}{l}\text { Train-hours of } \\
\text { delays of } \\
\text { suburban } \\
\text { electric trains } \\
\text { through the } \\
\text { fault of the } \\
\text { Traction } \\
\text { directorate }\end{array}$ & 370,8 & $\begin{array}{l}\qquad \Delta N t_{o p}^{s u b} * e_{N t}^{s u b} \\
\Delta N t_{o p}^{s u b}-\text { train-hours of delays of suburban electric } \\
\text { trains due to fault of locomotive depots and } \\
\text { maintenance }\end{array}$ & $-1,9$ \\
\hline \multicolumn{3}{|c|}{ Total for the Traction directorate } & 1372.21 \\
\hline & & TOTAL & 1390.5 \\
\hline
\end{tabular}

\section{Conclusions}

The conclusion of economic effect determination allows to estimate the most significant improvements in qualitative parameters of conveyance process and to form the motivational component of the involved affiliates. The researches in this problem and systemic management of operational work quality makes it possible to develop a set of motivational and investment nature measures and to counteract the risk of quality loss and reduce the financial result.

\section{References}

1. L.V. Shkurina, Evaluation of the economic and technological potential of rail transport in the formation of a competitive strategy (RGOTUPS, Moscow, 2003)

2. D.A. Macheret, A.V. Ryzhkov, Management of economic efficiency of operational activities of railway transport using an innovative approach (RIOR, Moscow, 2018)

3. L.V. Shkurina, E.A. Maskaeva, A.A. Alferova, Economic management of the competitiveness of railways (VINITI RAS, Moscow, 2018) 